\section{JIBM}

Journal of International Business and Management (JIBM) Journal Homepage: https://rpajournals.com/jibm

\title{
The Fintech Sensation - What is it about?
}

\author{
Johannes Treu \\ IU - International University of Applied Sciences, Germany
}

\begin{abstract}
The years following the 2008 financial crisis have been characterized by the emergence of new financial service providers, called fintech. The term is defined and understood differently in the literature. There is an agreement that fintech is composed of the words "financial" and "technology". Regarding the different views and definitions, there is great heterogeneity in the literature and this article tries to systematize them. Furthermore, different justifications for its existence are examined and a proposal for categorization is made. Argumentatively, various opportunities and risks are highlighted that arise in connection with Fintech. Finally, various ideas and starting points for further research are derived from the arguments.
\end{abstract}

Keywords: Fintech, Tech innovation, Financial technology

\section{*Corresponding author: Johannes Treu; Email: johannes.treu@iu.org DOI: https://doi.org/10.37227/JIBM-2021-11-2094}

\section{Introduction}

In production, the term Industry 4.0 is used to describe or classify the next step in industrialization. The simple and overrated buzzword digitization is used as the driver of this development. For example, companies are using a wide range of new communication and information technologies in manufacturing to enable machines and production systems to communicate with each other, to order materials independently, and to link customer needs and production efficiency more closely via cloud services and the Internet of Things. The structural change associated with the buzzword digitization does not stop at individual industries or sectors but is a classic economic phenomenon in the sense of the "process of creative destruction" according to Joseph A. Schumpeter (1947). Schumpeter sees the trigger for creative destruction as innovations that are driven by entrepreneurs to gain acceptance on the market.

In the banking and finance sector, however, innovations are much more difficult to find and differ from the classic characteristics, such as product or organizational innovations, that normally occur in other industries. Moreover, banks are not considered the developers of financial innovations. Rather, the banking and financial sector is an end-user of innovations developed in other sectors (Arnaboldi \& Rossignoli, 2015). Paul Volcker (2009) sums up this situation in his New York Post statement by saying, "The only thing useful banks have invented in 20 years is the ATM."

Despite the negative description regarding the ability to innovate, the banking and financial sector cannot completely shut itself off from change or innovation. A high number of Internet and smartphone users, technological progress, and a loss of trust as a result of the 2008/2009 financial crisis have also led to the further development of the digitization of financial services in this sector. For example, in the last eleven to twelve years after the end of the financial crisis, some financial technology start-ups have entered the market and developed innovative solutions to problems in the 
traditional banking, insurance, and asset management sectors. This newly burgeoning industry has become known as fintech and is growing at a rapid pace (Chemmanur et al., 2020).

Since the buzzword and the term fintech can be used to describe a great deal, and because the topic is highly topical with different ideas and perspectives, the first aim of this article is to examine the various perspectives and definitions. The second objective is to identify the reasons for the emergence of fintech. The final objective is to provide an outlook on possible theses and ideas for further research approaches, building on the work done previously.

\section{Research Methodology}

In terms of methodology, the article uses the Systematic Literature Review. This is an independent scientific method that aims to identify and evaluate relevant literature on a topic to derive its own conclusions for the research question (Nightingale, 2009; TU Berlin, 2019). The chosen method allows to show the current state of research on a topic as well as to identify gaps and research needs about a chosen objective (TU Berlin, 2019). Furthermore, the method allows for the investigation of contradictory and/or consistent findings. Additionally, there is the possibility to evaluate the consistency and generalizability regarding specific scientific questions and their practical significance within the chosen scientific field. Besides, the method is particularly useful to integrate information from a group of different studies or papers investigating the same phenomenon (Štrukelj, 2018).

Other advantages of the chosen approach include that it is among the best methods to summarize and synthesize evidence for a given research question (Štrukelj, 2018). Furthermore, it has a good validity compared to other scientific papers, as there is no personal relation to the chosen articles and therefore no conflict of interest. In addition, the method follows, among other things, the approach to include and critically evaluate older works, articles in low impact journals and/ or conference papers, non-empirical works and minority opinions as well as negative opinions on the prevailing mainstream in the respective scientific discipline (Nightingale, 2009). Also considered an advantage, the method is more than a mere description and inventory of the literature, as it seeks to refine or modify or improve research findings, research methods, definitions, constructs, etc. through nuance or gradation (Durach et al., 2017). In addition, the method can be used to narrow the gap between management/economics research and practice by illuminating and revealing hidden areas of reality in theories (Durach et al., 2017).

Regardless of the field, discipline, or philosophical perspective, a multi-step process is chosen, usually consisting of six to eight steps (Durach et al., 2017; Strukelj, 2018; TU Berlin, 2019). For example, according to Durach et al. (2017), the following steps are part of applying the method: (1) defining the research question(s), (2) determining the required characteristics of literature, (3) obtaining potentially relevant literature, (4) selecting relevant literature, (5) synthesizing the literature, and (6) reporting the results.

The application of the method, according to the presented six steps, is as follows for the present article. The first step, the definition of the research question or the aim of the paper has already been done in Chapter 1. Step 2 refers to the definition of keywords and key phrases. For this purpose, terms such as "fintech", fintech startup", financial innovation", "fintech industry" "fintech market", "innovations in the financial sector" and "fintech regulation" are defined. The listed terms are also supplemented with their English translations. Step 3 addresses the search/retrieval of potentially relevant literature in numerous electronic literature databases. These include GBV, EconBiz, IDEAS/RePEc search, and EconPapers. The advantage of these databases is a high percentage of open access papers, open access journals, and for paid journal articles, access to prepublication or preprints.1 For paid articles, the databases include an abstract or summary and a link to access available through libraries. The actual search is designed as a keyword search and keyword search. The selection of relevant literature takes place according to various criteria. For example, the

For example, Ideas/Repec and EconPapers contain 3.4 million items of research and over 3.1 million downloadable items of research. Econbiz also contains over 11.0 million entries. 
article must be written in English. Within the abstract or the introduction, there must be a significant reference to the generic term Fintech. This implies that the main part of the respective paper must explicitly deal with fintech and not treat this topic as a side note or in a paragraph. Further criteria are free availability or open access, a reference to the description and definition of the fintech phenomenon, and the integration of fintech into the financial system. In the next step, the selected titles are analyzed in terms of content, first reading the abstract or introduction and summary. Subsequently, they are read completely several times and the required information is extracted and the quality of the publications is evaluated. Since the evaluation of these, especially in the field of economics, does not follow a generally valid scheme, for example in medicine, the quality assessment consequently depends on the research question(s) (TU Berlin, 2018). Step 6 takes place in the subsequent chapters. From the findings of the individual studies, a meta-level attempt is made to understand what similarities and differences exist between the publications, as well as what research gaps, research questions, etc. exist. (TU Berlin, 2018).

\section{Literature Review}

The birth of the term fintech dates back to the Financial Services Technology Consortium, a project initiated in the early 1990s by what is now Citigroup (Arner et al., 2015; Kerényi \& Molnár, 2017; Ratecka, 2020). The goal of the project was to overcome the bank's reputation of resisting technological collaboration with outsiders (Hochstein, 2015). The term fintech, along with Citigroup's participation in the emerging smart card forum, was intended to describe a new strategy for the company and underpin its open attitude.

Although nearly 30 years have passed since the term was first mentioned, it is understood in different ways (Schindler, 2018; Elsinger et al., 2018; Rupeika-Apoga \& Thalassinos, 2020; Allen et al., 2020). For example, market participants and regulators use different terms for the same activity or the same term for different activities. For example, the terms fintech lending, peer-to-peer lending, crowdlending, loan-based crowdfunding, or simply crowdfunding are often used interchangeably (Ehrentraud et al., 2020). The main challenge in defining the term fintech is the versatility of the prevailing applications and perspectives, as well as the fact that this phenomenon is in a very active stage of development (Rupeika-Apoga \& Thalassinos, 2020). Thus, Dorfleitner et al. (2020) state that the last point, in particular, is characterized by a dynamic growing market environment with the emergence of new business models and segments. Consequently, it is not surprising that there is no uniform definition or consensus regarding the term and that ambiguity prevails (Dorfleitner et al., 2016; Deutsche Bundesbank, 2016; Danker \& Bafin, 2016; Leonhardt \& BaFin, 2019; Das, 2019; Ehrentraud et al., 2020). Thus, a need for clear delineation and definition can be noted. This need arises, for example, from the fact that definitions and perspectives influence how regulators assess the fintech phenomenon to determine a specific approach to potential regulation, market development, data protection, consumer protection, etc. The importance of a clear delineation and definition of terms, especially about potential regulation, is also underlined by the Basel Committee on Banking Supervision (2018), which concludes that most authorities surveyed do not have a formal definition of fintech or similar. The same statement is made by the OECD (2018), which calls for a comprehensive framework to enable policymakers and regulators to better assess and evaluate the applications of digital technologies and their impact.

The consensus regarding the term is that fintech is composed of the words "financial" and "technology" (Hikida \& Perry, 2019; Mirchandani et al., 2020; Chemmanur et al., 2020; Ratecka, 2020). The neologism signifies an integration of technology into the offerings of financial services companies to improve their use and delivery to consumers. This etymological approach represents the minimum consensus of all definitions and perspectives. Furthermore, the reference is made to young technology-savvy companies so-called start-ups, which have recognized and are driving the trend towards digitalization and personalization in the financial market (Danker \& Bafin, 2016; Paddagas, 2017; Nathmann, 2019). However, the Deutsche Bundesbank (n.d.) and also the OECD (2018) state that the reference to start-ups does not have to be a prerequisite. 
The following table presents various views and definitions of the term fintech, which is intended to open up more than the mere etymological determination. At the same time, an attempt is made to establish a definitional focus to provide clarity and an overview. A similar approach, but smaller in scope, is also described by Ratecka (2020). Here, the author shows that fintech definitions are associated with the terms innovation and (service) technology. At the same time, the definitional determination of Fintech as (young) companies is emphasized. Similarly, the OECD (2018) sees fintech definitions as labels for companies and/or startups that offer and apply technologies. At the same time, however, these types of fintech definitions are seen by the OECD (2018) as not being "precisely defined in practice."

Table 1: Overview of Different Fintech Definitions

\begin{tabular}{|c|c|c|}
\hline Author & Definition and views of Fintech & Focus \\
\hline $\begin{array}{l}\text { World } \quad \text { Economic } \\
\text { Forum (2015) }\end{array}$ & $\begin{array}{l}\text { "...defined as the use of technology and } \\
\text { innovative business models in financial } \\
\text { services". } \\
\text { "FinTech embodies a new set of products tailored } \\
\text { to the needs of small businesses. These include } \\
\text { marketplace("peer-to-peer") lending, merchant } \\
\text { and e-commerce finance, invoice finance, online } \\
\text { supply chain finance, and online trade finance. }\end{array}$ & $\begin{array}{l}\text { technology-oriented } \\
\text { and function-oriented } \\
\text { focus }\end{array}$ \\
\hline Arner et al. (2015) & $\begin{array}{l}\text { "FinTech today comprises five major areas: (1) } \\
\text { finance and investment, (2) operations and risk } \\
\text { management, (3) payments and infrastructure, (4) } \\
\text { data security and monetization, and (5) customer } \\
\text { interface }\end{array}$ & $\begin{array}{l}\text { function-oriented } \\
\text { focus }\end{array}$ \\
\hline Yonghee et al. (2015) & $\begin{array}{l}\text { Fintech "in terms of financial services, it is an } \\
\text { innovative service which provides differentiated } \\
\text { financial services using new technologies, such } \\
\text { as mobile, social media, and IoT." }\end{array}$ & $\begin{array}{l}\text { technology-oriented } \\
\text { focus }\end{array}$ \\
\hline $\begin{array}{l}\text { Dorfleitner et } \begin{array}{l}\text { al. } \\
\text { (2016) }\end{array} \\
\end{array}$ & $\begin{array}{l}\text { The term FinTech, (...), describes companies or } \\
\text { units of existing companies that combine } \\
\text { financial services with modern, innovative } \\
\text { technologies." } \\
\text { "(...) FinTechs [can] be distinguished according } \\
\text { to the segments financing, wealth management, } \\
\text { payment transactions, and other FinTechs." }\end{array}$ & $\begin{array}{l}\text { technology-oriented } \\
\text { and function-oriented } \\
\text { focus }\end{array}$ \\
\hline $\begin{array}{l}\text { Danker } \quad \& \quad \text { BaFin } \\
(2016)\end{array}$ & $\begin{array}{l}\text { "(...) Fintechs [are] commonly understood to be } \\
\text { young companies that use technology-based } \\
\text { systems to offer specialized and particularly } \\
\text { customer-oriented financial services." }\end{array}$ & $\begin{array}{l}\text { technology-oriented } \\
\text { focus }\end{array}$ \\
\hline $\begin{array}{l}\text { Financial Stability } \\
\text { Board (2017) }\end{array}$ & $\begin{array}{l}\text { "FinTech is defined as technology-enabled } \\
\text { innovation in financial services that could result } \\
\text { in new business models, applications, processes } \\
\text { or products with an associated material effect on } \\
\text { the provision of financial services." } \\
\text { FinTech activities can be organized into five } \\
\text { categories: (i) payments, clearing, and } \\
\text { settlement; (ii) deposits, lending, and capital } \\
\text { raising; (iii) insurance; (iv) investment } \\
\text { management; and (v) market support. }\end{array}$ & $\begin{array}{l}\text { technology-oriented } \\
\text { and function-oriented } \\
\text { focus }\end{array}$ \\
\hline
\end{tabular}




\begin{tabular}{|c|c|c|}
\hline Paddags (2017) & $\begin{array}{l}\text { "In the following, FinTechs refer to companies } \\
\text { that, as start-ups or new players, provide new } \\
\text { impetus in the financial sector due to their IT } \\
\text { expertise and innovative strength, among other } \\
\text { things, and encompass the (...) business models } \\
\text { presented." } \\
\text { (i) credit intermediation, } \\
\text { crowdfunding/inversting, (iii) payment } \\
\text { transactions, (iv) investment advice. }\end{array}$ & $\begin{array}{l}\text { technology-oriented } \\
\text { and function-oriented } \\
\text { focus }\end{array}$ \\
\hline Schindler (2017) & $\begin{array}{l}\text { "I have adopted a definition used by the Financial } \\
\text { Stability Board" } \\
\text { "By my own estimation, items that would be } \\
\text { considered FinTech according to this definition } \\
\text { include (...): online marketplace lending (called } \\
\text { peer-to-peer lending by some), equity } \\
\text { crowdfunding, robo-advice, financial } \\
\text { applications of distributed ledger technology, and } \\
\text { financial applications of machine learning..." }\end{array}$ & $\begin{array}{l}\text { technology-oriented } \\
\text { and function-oriented } \\
\text { focus }\end{array}$ \\
\hline Varga (2017) & $\begin{array}{l}\text { "Fintech refers to non- or not fully regulated } \\
\text { ventures whose goal is to develop novel, } \\
\text { technology-enabled financial services with a } \\
\text { value-added design that will transform current } \\
\text { financial practices" }\end{array}$ & $\begin{array}{l}\text { technology-oriented } \\
\text { focus }\end{array}$ \\
\hline $\begin{array}{l}\text { Philippon } \\
\text { 2019) }\end{array}$ & $\begin{array}{l}\text { "Fintech covers digital innovations and } \\
\text { technology-enabled business model innovations } \\
\text { in the financial sector." }\end{array}$ & $\begin{array}{l}\text { technology-oriented } \\
\text { focus }\end{array}$ \\
\hline $\begin{array}{l}\text { Basel Committee on } \\
\text { Banking Supervision } \\
\text { (2018) }\end{array}$ & $\begin{array}{l}\text { "The BCBS has opted to use the Financial } \\
\text { Stability Board's (FSB) working definition for } \\
\text { fintech... In addition to the FSB definition, the } \\
\text { BCBS also used a categorization of fintech" (i) } \\
\text { credit, deposit, and capital-raising services, (ii) } \\
\text { payments, clearing and settlement services, (iii) } \\
\text { investment management service }\end{array}$ & $\begin{array}{l}\text { Technology-oriented } \\
\text { and functionally } \\
\text { oriented focus }\end{array}$ \\
\hline Elsinger et al. (2018) & $\begin{array}{l}\text { "...we define fintech in a rather broad sense, } \\
\text { including all technologically enabled financial } \\
\text { innovations with material effects on markets, } \\
\text { households, and businesses." }\end{array}$ & $\begin{array}{l}\text { technology-oriented } \\
\text { focus }\end{array}$ \\
\hline IMF (2018) & $\begin{array}{l}\text { Fintech is "the advances in technology that have } \\
\text { the potential to transform the provision of } \\
\text { financial services spurring the development of } \\
\text { new business models, applications, processes, } \\
\text { and products." }\end{array}$ & $\begin{array}{l}\text { technology-oriented } \\
\text { focus }\end{array}$ \\
\hline OECD (2018) & $\begin{array}{l}\text { "Fintech involves not only the application of new } \\
\text { digital technologies to financial services but also } \\
\text { the development of business models and products } \\
\text { which rely on these technologies and more } \\
\text { generally on digital platforms and processes." } \\
\text { Areas are "payments, planning, lending and } \\
\text { funding, trading and investment, insurance, } \\
\text { cybersecurity, operations, and communication." }\end{array}$ & $\begin{array}{l}\text { technology-oriented } \\
\text { and function-oriented } \\
\text { focus }\end{array}$ \\
\hline
\end{tabular}




\begin{tabular}{|c|c|c|}
\hline $\begin{array}{l}\text { European Parliament } \\
\text { (2018) }\end{array}$ & $\begin{array}{l}\text { "FinTech may be understood as finance enabled } \\
\text { by new technologies covering the whole range of } \\
\text { financial services, products, and infrastructure" }\end{array}$ & $\begin{array}{l}\text { technology-oriented } \\
\text { focus }\end{array}$ \\
\hline Das (2019) & $\begin{array}{l}\text { "Fintech is any technology that eliminates or } \\
\text { reduces the cost of financial intermediation." }\end{array}$ & $\begin{array}{l}\text { technology-oriented } \\
\text { focus }\end{array}$ \\
\hline Thakor (2019) & $\begin{array}{l}\text { "...fintech is the use of technology to provide new } \\
\text { and improved financial services." } \\
\text { "The areas that fintech covers can be broadly } \\
\text { described as (i) credit, deposits, and capital- } \\
\text { raising services; (ii) payments, clearing, and } \\
\text { settlement services, including digital currencies; } \\
\text { (iii) investment management services (including } \\
\text { trading); and (iv) insurance." }\end{array}$ & $\begin{array}{l}\text { technology-oriented } \\
\text { and function-oriented } \\
\text { focus }\end{array}$ \\
\hline $\begin{array}{l}\text { Imerman \& Fabozzi } \\
(2020)\end{array}$ & $\begin{array}{l}\text { "...FinTech refers to the application of new } \\
\text { technology in providing financial solutions to } \\
\text { individuals and firms." }\end{array}$ & $\begin{array}{l}\text { technology-oriented } \\
\text { focus }\end{array}$ \\
\hline $\begin{array}{l}\text { Ehrentraud et al } \\
(2020) \text {. }\end{array}$ & $\begin{array}{l}\text { "...we adopt the FSB's working definition for } \\
\text { Fintech." } \\
\text { "To characterize the fintech environment, we } \\
\text { distinguish three categories: fintech activities, } \\
\text { enabling technologies and policy enablers." } \\
\text { "...fintech activities can be found in the following } \\
\text { financial services categories: (i) deposits and } \\
\text { lending; (ii) capital-raising and alternative } \\
\text { sources of funding; (iii) asset management, } \\
\text { trading, and related services; (iv) payments, } \\
\text { clearing, and settlement services; (v) insurance; } \\
\text { and (vi) crypto assets. }\end{array}$ & $\begin{array}{l}\text { technology-oriented } \\
\text { and function-oriented } \\
\text { focus }\end{array}$ \\
\hline $\begin{array}{l}\text { Mirchandani et al } \\
(2020) \text {. }\end{array}$ & $\begin{array}{l}\text { "Fintech can be broken down into several } \\
\text { different areas within the financial sector..." (i) } \\
\text { asset management, (ii) cryptocurrency, (iii) } \\
\text { crowdfunding, (iv) investment management, (v) } \\
\text { marketplace lending }\end{array}$ & functional focus \\
\hline $\begin{array}{ll}\text { European } & \text { Central } \\
\text { Bank }(2020) & \end{array}$ & $\begin{array}{l}\text { Fintech is a term used throughout the response to } \\
\text { refer to financial technology - in the ECB's view } \\
\text { an umbrella term for any kind of technological } \\
\text { innovation used to support or provide financial } \\
\text { services that could result in changes to business } \\
\text { models, applications, processes, or product }\end{array}$ & $\begin{array}{l}\text { technology-oriented } \\
\text { focus }\end{array}$ \\
\hline $\begin{array}{l}\text { Chemmanur et al. } \\
(2020)\end{array}$ & $\begin{array}{l}\text { "Fintech (...) refers to the use of latest technology } \\
\text { in solving problems in financial services (...)." } \\
\text { "The Fintech Ecosystem can broadly be divided } \\
\text { into following eight industry segments: (i) } \\
\text { payments and money transfer, (ii) digital } \\
\text { banking, (iii) digital wealth management (...), (iv) } \\
\text { capital markets innovations, (v) Fintech lending } \\
\text { (...), (vi) equity crowdfunding, (vii) InsureTech } \\
\text { (...) and (viii) PropTech (...)." }\end{array}$ & $\begin{array}{l}\text { technology-oriented } \\
\text { and function-oriented } \\
\text { focus }\end{array}$ \\
\hline Beck (2020) & $\begin{array}{l}\text { "On the one hand, fintech can refer to the } \\
\text { integration of technology into product and } \\
\text { service offerings by financial service providers to } \\
\text { improve their use and delivery to consumers. On }\end{array}$ & $\begin{array}{l}\text { technology-oriented } \\
\text { focus }\end{array}$ \\
\hline
\end{tabular}




\begin{tabular}{|l|l|l|}
\hline & $\begin{array}{l}\text { the other hand, it can also be understood as new } \\
\text { technology-driven players that aim to compete } \\
\text { with traditional financial institutions in the } \\
\text { delivery of financial services." }\end{array}$ & \\
\hline Goo \& Heo (2020) & $\begin{array}{l}\text { "Fintech (...) revolves around providing } \\
\text { traditional financial services in new forms using } \\
\text { technology." }\end{array}$ & $\begin{array}{l}\text { technology-oriented } \\
\text { and function-oriented } \\
\text { focus }\end{array}$ \\
& $\begin{array}{l}\text { "Different areas of the fintech industry range } \\
\text { from payment, billing, lending, wealth } \\
\text { management, money transfer, mortgage, and real } \\
\text { estate to insurance, personal finance, capital } \\
\text { market, blockchain, and cryptocurrency personal } \\
\text { finance, capital market, blockchain, and } \\
\text { cryptocurrency." }\end{array}$ & \\
\hline Deutsche & $\begin{array}{l}\text { "In general, this term describes companies that } \\
\text { provide innovative, technology-based and } \\
\text { finance-related application systems" }\end{array}$ & technology-oriented \\
"Thematically, the term "fintech" in its practical \\
"The covers a variety of different technology- \\
based business models (...)."
\end{tabular}

The definitions listed in Table 1 show that they can be divided into three groups. Some definitions have a technology-oriented focus and are therefore closely aligned with the etymological definition. However, these views leave out what innovative technologies are or paraphrase them with the term disruptive innovation or technology. This definitional approach tends to omit innovations that are based on existing technologies (e.g., smartphones, digital payments, mobile internet, etc.) (OECD 2018), which is particularly true for the fintech sector. Furthermore, it is clear that technologyoriented definitions prevail at the institutional level, such as the IMF, BaFin, Deutsche Bundesbank, and ECB. Why this is so may need more clarification. The second view includes a purely functional focus and refers to possible financial market services or financial market functions. Here, the definitions differ in terms of content in that the determination of functions and/or services is very heterogeneous. This definitional approach also leaves out the reference to the use of technologies and thus fails to distinguish fintech from classic financial market services or financial market functions and to emphasize its novelty.

The third group of definitions combines the first two and consequently has a technologyoriented and function-oriented focus. This broader approach also leaves out distinguishing what innovative technologies are. At the same time, however, it has a stronger market reference, as it focuses on financial market services or financial market functions while at the same time determining the novelty of fintech through the use of technologies. Within the third group, there is also a great deal of heterogeneity about financial market services or financial market functions, which makes it difficult to determine precisely at the functional level. Here, further, development must show which Fintech financial market services or financial market functions will prevail evolutionarily, in line with the thinking of Joseph A. Schumpeter.

\section{Results and Analysis}

\section{Evolutionary Emergence and Current Situation}

Although the current fintech term can be located in the 21 st century, its development goes back more than 150 years. As early as the 19th century, technological innovation was used to increase the efficiency of doing business in the financial sector (Arner et al., 2015; Nathmann, 2019). The invention and use of telegraphy is the first example. With the help of this technology and using the first transatlantic telegraph cable, the financial centers of New York and London were connected. 
Also, as early as 1870 , the Western Union company offered money transfers to its customers using telegraphs (Nathmann, 2019; Thakor, 2019, Hikida \& Perry, 2019). Starting with this first development, the evolution of Fintech is divided into three phases with different new technologies.

The first phase (Fintech 1.0) spans from 1866-1967, describing a situation in which telegraphy was used to speed up financial transactions and transmit financial information. (Arner et al., 2015; Thakor, 2019). The next innovative step in this period begins with the end of World War II and progressive development in the field of communication and information technology. Important milestones here include the first "code-breaking tools" that were commercially developed on early computers by companies such as International Business Machines. The invention of the first pocket calculator by Texas Instrument also falls into this first fintech period. Further, the 1950s was a time when new credit card providers debuted in the U.S. banking services market, e.g., Diners Club in 1950 and American Express in 1958. This consumer revolution was further supported by the creation of the Interbank Card Association, now MasterCard, in the United States in 1966 (Arner et al., 2015, Ratecka, 2020).

The second phase (Fintech 2.0) is described as the development from the analog to the digital age and ranges from 1967-2008 (Arner et al., 2015; Thakor, 2019). The beginning of this period is stated to be 1967 and coincides with the development as well as the first use of the ATM. Other technological developments in this period include the advancement of the electronic payment system "Fedwire" which started in 1970 and the development of online banking for customers which started in 1980 in the US and 1983 in the UK. Also, the increasing use of Bloomberg terminals from 1984 and the "triumph" of the Internet are part of this period (Arner et al., 2015, Ratecka, 2020). All these technological developments aim to improve product and service quality in the financial sector through their use (Thakor, 2009).

The third phase (Fintech 3.0) begins in 2008 and extends to the present (Arner et al., 2015; Thakor, 2019). Here, the 2008 financial crisis is seen as the starting point for the new phase. The situation of loss of confidence and uncertainty that prevailed at that time favored the emergence of innovative companies that used financial and technological know-how for their activities. At the same time, from the point of view of private customers, a rethinking began in the direction of who had the resources and legitimacy to offer financial services. The result is the realization that financial services are no longer offered only by regulated financial institutions. The basis for the dynamic development in this phase are new technologies, e.g. artificial intelligence (AI) and machine learning, databases (Big Data), distributed computing, cryptography, and mobile Internet access, which lead to the emergence of new applications and new providers for financial services (Arner et al., 2015, Ratecka, 2020).

Within the third phase, the emerging markets, especially Asia, occupy a special position. The reason for this is that fintech developments are less the result of a loss of confidence after 2008 and more the result of the pursuit of economic development. For example, there are less competitive and regionally differentiated banking markets in the Asian region, as the entire system is heavily controlled and distorted by state-owned banks. Also, public distrust of the state-owned banking system (due to corruption and inefficiency) leads the public to quickly accept new financial alternatives offered by non-banks. Thus, the development in Asia is not a new post-crisis paradigm but a combination of entrepreneurial forces and is referred to as Fintech 3.5 by Arner et al. (2015).

That the FinTech sector is an emerging and fast-growing sector can be shown by further facts (Statista Research Department, 2021a; Statista Research Department, 2021b; Statista Research Department, 2020) For example, the total value of investments in FinTech companies worldwide increased from nine billion U.S. dollars in 2010 to 168 billion U.S. dollars in 2019. Due to the global Corona crisis in 2020, the level has decreased by slightly more than one-third. Additionally, the number of startups is used as an indicator of growth. Here, the number of FinTech companies worldwide more than doubled between 2018 and February 2021. As another indicator of an emerging growth industry, the amount of global venture capital investment can be used. Here, venture capital investments in FinTech companies worldwide have increased from $\$ 1.89$ billion in 2010 to $\$ 53.3$ billion in 2019 . 


\section{Reasons for the Emergence of Fintech}

Arguments and reasons for the emergence of fintech are as numerous as the various definitions and perspectives. It is precisely this prevailing heterogeneity that is responsible, among other things, for the fact that a large number of different justifications exist. One way of explaining the emergence of fintech is through the innovation approach. In doing so, this type of justification is oriented towards the technology-oriented view of the term fintech and moves the term disruptive innovation or technology more into the center of justification, for example in Kerényi \& Molnár (2017) or Fáykiss et al. (2018). The general understanding of this term according to Christensen (2011) is applied to the fintech phenomenon. According to this, one cause of the appearance of Fintech is the existence of disruptive innovations or technologies that replace the success series of existing technology, product, or service, or completely displace it from the market. To distinguish fintech more strongly from technological progress, this justification approach strongly emphasizes that market conditions are disrupted at their core and on an unprecedented scale, and that technological innovations are capable of fundamentally changing existing business models (Kerényi \& Molnár, 2017; Fáykiss et al. 2018). Even though a modern buzzword such as disruptive innovation or technology is used in this justification approach, this cannot hide the fact that from an economic history perspective, classical economists such as Smith, Schumpeter, or Kondratieff already saw innovations as the reason for the occurrence of market change and economic growth. Consequently, this reasoning approach falls short and further leaves open which types of technologies are responsible for the occurrence of fintech in the first place. Nor does it separate the use of existing technologies, which is not news in a strict sense, from the development of new technologies for the fintech market. This seems necessary, however, since the fintech industry uses existing technologies and innovations rather than developing them itself through R\&D activities.

Philippon $(2017,2019)$ provides another motive for the existence of fintech by showing that the current financial system in the USA is inefficient. The reason for this is the high cost of financial intermediation, which historically has been at a level that is always the same. For example, Philippon $(2017,2019)$ shows that the average cost of financial intermediation has been constant at about $2 \%$ of transaction amounts. Consequently, financial services have been quite expensive in recent decades, and this is despite the advent of computers, electronic trading in financial markets, and other innovations (Frost 2020). According to this view, finance can be seen as an industry with inefficient regulation, barriers to entry, and increasing returns to firm size. Due to these causes, the emergence of fintech is explained, which thus have an incentive to "rent-seeking and business stealing" Philippon (2017). In this approach, the use of technology is a catalyst for more competition and consequently should bring efficiency gains in financial intermediation. The emergence of fintech is therefore explained by purely economic considerations in terms of maximizing the profits of economic agents.

Further reasons are provided by Claessens et al. (2018), who cite a country's economic growth, the level of economic and financial development, and the quality of legal institutions, among other factors. According to them, there is a positive correlation between a country's level of development and the appearance of fintech. The state of financial regulation can also account for the existence of Fintech. On the one hand, strict regulation may increase confidence in new forms of financial intermediation. At the same time, however, less intense regulation of fintech activities may also contribute to their growth. Here, Claessens et al. (2018) show that a negative correlation exists between fintech activities and the stringency of bank regulation. Claessens et al. (2018) further argue that the emergence of fintech may also be related to the intensity of competition in credit markets. For example, it is possible that a less competitive banking system means higher margins for bank loans and consequently boosts alternative forms such as fintech. Moreover, if information about borrowers is better assessed and customers are more easily reached, fintech firms may be more prevalent in countries where access to credit is more difficult. Using regression analysis, the authors show that fintech lending is higher in countries with a less competitive banking sector. Consequently, competition can be seen as a determinant of the appearance of fintech companies. All of the above 
reasons target aggregate macroeconomic variables and are measured across countries. At the macroeconomic level, they provide a first building block to explain the emergence of fintech. For further determinants and to explore whether there are country-specific differences, a cross-country comparison would be the next logical step. Since fintech is also a young phenomenon that is at the beginning of its (market) life cycle and is experiencing a strong (positive) trend, it remains to be seen how the results will change when market shakeout tendencies set in, the economic situation changes or macroeconomic shocks occur.

Schindler (2016) and Frost (2020) provide the argument that macroeconomic conditions, in particular the low-interest-rate environment and monetary policy, could help support the emergence of fintech. The current macroeconomic environment is squeezing financial institutions' profits and creating an incentive to cut costs. Young fintech companies have recognized this situation and are using technology to focus on reducing costs. However, even though this theoretical argument sounds very plausible, Frost (2020) weakens it by noting that so far there is no cross-country evidence of a link between low-interest rates and fintech lending volumes. Regardless of the empirical investigation, however, this theoretical argument for the emergence of fintech should remain valid. Another way to make a case for the existence of fintech is to look at supply and demand drivers. This approach builds on the work of Schindler (2016), Financial Stability Board (2017, 2019), Vučinić (2020), and Branzoli \& Supino (2020). Thus, on the supply side, the availability of application programming interfaces (APIs) are mentioned, which serve the purpose of communicating with each other and exchanging data.

In this context, the implementation of these interfaces enables service improvements, especially in the immediacy of payments (Financial Stability Board 2019). In conjunction with API, the supply side also cites the availability of mobile banking and smartphones for the existence of fintech. Smartphones serve as a platform for third-party developers to build new products. Combined with APIs, today's smartphones have payment functions built into their systems that are available to any user. Cloud computing can be cited as a third supply driver. The availability of cloud computing brings different benefits when combined with fintech, such as flexibility, economies of scale, operational and cost efficiencies. For example, fintech companies typically use clouds for managing customer relationships, human resources, and financial accounting (Financial Stability Board, 2019; Vučinić, 2020).

Additional motives for the emergence of fintech on the supply side are reforms in financial regulation since the 2008/2009 financial crisis. Following the crisis, regulatory and supervisory requirements have changed and evolved, influencing the emergence of new fintech companies (Schindler, 2016; Financial Stability Board, 2019; Vučinić, 2020). For example, competition issues are feeding into financial regulation, with regulators in many countries gaining new powers regarding the design of the competition. In general, ensuring competition has become an explicit objective of regulatory policy. Thus, policies have been developed that relate to the promotion of competition around open banking. One example of such new regulation in the European Union is the PSD2 Payment Services Directive, revised in 2015. PSD2 provides a legal basis for the development of an integrated single market in the EU that includes more efficient, simpler, and safer electronic payments. The aim is to open up the EU market to new entrants, leading to more competition and better prices. PSD2 provides for open access to certain types of banking data for licensed providers of payment initiation services and account information services, which are now allowed to retrieve information about personal online banking accounts (Financial Stability Board, 2019; Vučinić, 2020). In addition, national and international data protection regulations may also have an impact on the level of competition and thus influence the ability of new entrants to enter the fintech market. Particularly in the case of differing regulations in this regard, the possibility may arise for young fintech companies to expand internationally into regions with looser regulations.

Demand-oriented justifications for the existence of fintech relate to the fact that customers' expectations and preferences have changed. For example, on the one hand, the 2008 financial crisis led to a loss of confidence in the established financial system and thus to a search for new and young alternatives outside the system. On the other hand, consumers today demand fast, easy, inexpensive, 
and secure payments at any time and from any place. Demographic changes are also considered to be driving demand, especially because of the growing financial influence of digital natives or millennials. Thus, this generation is more willing to adopt fintech services than similar services offered by traditional banks, which are associated with high personal and social barriers (Schindler, 2016; Financial Stability Board, 2019; Vučinić, 2020). In addition, this user group may have positive network externalities that further influence demand. For example, the more users there are on a digital currency or crowdfunding platform, the more likely they are to be used for transactions and the more value each user achieves (Financial Stability Board, 2016).

\section{Fintech Opportunities}

More generally, the fintech phenomenon offers the opportunity to avoid market frictions as well as information asymmetries and the resulting agency conflicts between lenders and borrowers (Amstad, 2019; Beck, 2020). This leads to more convenience for users, lower transaction costs, and better credit risk scores (Claessens et al., 2018; Beck 2020). The last point, in particular, is supported by Berg et al. (2018), who show that the digital footprint could provide a better way to screen borrowers. Similarly, Bartlett et al. (2018) show that fintech algorithms discriminate in lending up to $40 \%$ less than in-person lenders. For example, fintech giants Alibaba and WeChat, as well as Tencent's Pay Points Credit in China, have built a new credit scoring system based on alternative data that draws from nontraditional sources such as social media, online shopping, payment apps, cell phone accounts, and the like. This type of scoring provides a more comprehensive view of consumers' financial lives and is expected to help close the credit gap for people who are unable to obtain credit due to their lack of credit history (Allen et al., 2020).

The overall benefit of reducing market inequality through fintech leads to the opportunity that fintech can be used to drive financial inclusion. This means that individuals and businesses have access to financial products and services that meet their needs and are delivered responsibly and sustainably (World Bank, 2018). For example, an estimated 1.7 billion adults worldwide do not have access to a transaction account and are excluded from the formal financial system. Financial inclusion, as noted by the G20, is one of the critical drivers of poverty reduction and economic growth in emerging and developing economies (World Bank 2020). There is also macroeconomic evidence that economies with deep and diverse financial intermediation tend to grow faster and reduce income inequality (Beck et al., 2007). Fintech companies can step into this gap by having already changed the financial landscape over the past decade. For example, reduced costs of providing financial services, better organizational structures, and more effective risk management have helped expand financial inclusion in many developing countries, as well as demand for financial products and services (Beck, 2020).

Another opportunity can be seen in improving global financial stability. For example, fintech companies may have the potential to improve the degree of decentralization and diversification of the financial system, which could mitigate the impact of future financial shocks. This is made possible by (Financial Stability Board, 2017; Claessens et al., 2018; Fáykiss et al., 2018):

- A greater variety of credit or financing sources (compared to a situation where a few banks dominate lending).

- a low level of correlation (compared to other asset classes)

- better credit allocation (compared to a situation where credit allocation is limited due to asymmetric information)

- more efficient pricing (compared to the state-regulated banking sector or existing monopoly. -or oligopoly structure)

Furthermore, the increased emergence of fintech firms may reduce the market concentration of established financial firms, decreasing the number of systemically relevant institutions. At the same time, a higher number of financial firms may enable the government to revive credit markets after a crisis (Claessens et al., 2018; Fáykiss et al., 2018).

In addition, fintech offers the opportunity for general efficiency improvements through (Financial Stability Board, 2017, 2019; OECD, 2018; Fáykiss et al., 2018; Philippon, 2019; Baba et al. 2020): 
- More efficient, convenient, and cost-effective provision of financial services

- Improving the customer experience and thus better diversification of investment risk

- increased competition

- Less dependence on geographical proximity to financial services or products and thus reduction of the branch network

- More transparency to improve market participants' management of financial risks

- Streamlining back-office functions

- General welfare gains

- Optimization of decision-making processes and thus faster completion of transactions

\section{Fintech Risks}

In addition to the advantage of potentially better financial intermediation, the phenomenon also entails risks or raises new questions. For example, it is not clear to what extent fintech companies should be included in the existing regulatory framework of the financial system. Insofar as fintech is subject to the same risks and forms of activity as traditional or existing financial intermediaries, they must not be given preference over others following the principle of neutrality. At the same time, however, it is important to ensure that regulatory requirements do not hinder innovation and market entry. This point may be particularly important in emerging economies, where efficiency benefits and benefits from easier access to credit are high (Claessens et al., 2018). Moreover, the fintech market or industry is characterized by a high degree of heterogeneity, which on the one hand complicates regulation and on the other hand requires regulation to limit critical excesses on time. Consequently, the risk of a regulatory dilemma may arise between achieving a balance of prudential rules and promoting fintech innovation while maintaining financial stability. Fáykiss et al. (2018) see a similar risk between laissez-faire and excessive restrictions in fintech. To solve this dilemma, it is possible to establish "regulatory sandboxes." This is an approach to test new technologies in a controlled environment, trying to find the balance between innovation and existing regulatory rules (Claessens et al., 2018; Fáykiss et al., 2018).

Other risks associated with fintech are referred to as microeconomic and macroeconomic risks by the Financial Stability Board (2017), Fáykiss et al., (2018), and Vučinić (2020). The former refers to risks that make individual firms or sectors particularly vulnerable to shocks. These shocks carry the risk of triggering a situation that can have systemic effects on the entire financial system. This risk is fed by various financial and operational sources (Financial Stability Board,2017; Fáykiss et al., 2018; Vučinić, 2020):

- Maturity mismatch (financial) - means that a loan is extended for a longer period than is contracted to finance it, consequently rollover risk may arise. Systemic impact could arise if the sector provides critical functions or services, as is the case with fintech lending.

- Liquidity mismatch (financial) - occurs when assets and liabilities have different liquidity characteristics, leading to "run risk" and thus the need to liquidate relatively illiquid assets quickly, disrupting markets.

- Leverage (financial) - a higher leverage ratio means that less equity is available to absorb any losses arising from market, credit, or other risks. Fintech companies could borrow to finance the temporary holding of bond or equity issues, increasing their financial risk.

- Activities outside or with little regulation (operational) - Third-party providers offering services to regulated financial institutions may not be subject to the same level of oversight or scrutiny of their governance and business processes that regulated financial institutions are subject to.

- Cyber risks (operational) - Cyber attacks are a growing threat. Fintech companies can amplify this risk, as the risk increases the more different institutions are connected. More technology and digital solutions also provide more points of attack that can be exploited by hackers. 
- Dependence on third-party providers (operational) - Fintech activities rely on third-party services, such as cloud computing or telecommunications provision. Systemic risk increases when these third-party providers run into operational difficulties and the stronger the link between fintech companies and institutions.

- Critical business size (operational) - should fintech companies become critical in size, e.g., too big to fail, losses may risk impacting the delivery of critical services and hinder recovery or orderly exit

- Data quality and data protection (operational) - Fintech operations are characterized by a high volume of data, its use, and analysis. Due to deficiencies in data processing or data quality problems, automated processes and analyses can lead to incorrect results. This poses the risk of monetary losses for customers or unauthorized data use.

Innovations may also have the potential to create macroeconomic risks over time, amplifying potential shocks to the financial system and increasing the likelihood of financial instability. The extent to which financial innovations can have an impact and become a source of financial risk depends on the nature of the innovation and its potential to evolve. Potential risks include (Financial Stability Board,2017; Fáykiss et al., 2018; Vučinić, 2020):

- Contagion risk - Problems that occur at a single institution or in one sector can spread to other institutions or sectors. Reputational contagion, in particular, is a potential risk for fintech. Large and unexpected losses that occur on a fintech platform can spread to the entire sector, destabilizing the entire system.

- Procyclicality - commercial bank lending is procyclical, as banks tend to loosen their lending terms when the economy is booming, while they tighten their lending during an economic downturn. Fintech companies can reinforce the procyclical functioning of the financial sector, on the one hand through automated and engineered decision making that follow similar patterns, and on the other hand through intensifying market competition with established financial intermediaries.

- Volatility - the financial system tends to overreact to emerging information. The increasing prevalence of fintech may cause the financial system to react with greater sensitivity to specific industry news and changes, increasing volatility at the systemic level.

- Systemic relevance - Firms that are considered systemically important (or too interconnected to fail) may amplify moral hazard risks by, for example, taking excessive risks because the downside is limited by the implicit guarantee of public support. In the context of fintech, the market structure may evolve to create highly interconnected clusters or to form oligopolies or monopolies to the collection and use of customer information necessary to provide financial services. This market structure can then amplify the risk of moral hazard.

Another risk in the fintech sector can be the formation of a possible speculative bubble. Minsky's model for the formation of such bubbles or the Minsky paradox can be used to describe this risk (Minsky, 1978, 1992). This describes how a financial crisis can occur despite a booming economy. Thus, according to Minsky, financial crises are endogenous in a capitalist economic system and the inherent behavior of market participants is causative for speculative bubbles. According to Heim (2013), the development of this instability can be described by the following phases. The beginning is an exogenous event or shock. This causes a change in the expectations of market participants and thus a shift of investments to another sector of the economy. The next phase is characterized by increasing investment, price increases, and liquidity, which attracts additional investors. Furthermore, there is an increase in debt financing through borrowing to cover the increased capital requirements for investments. In the third phase, euphoria prevails and risks are ignored. The increased credit-financed investments lead to rising interest rates because of the expansion of lending. The fourth phase begins with, for example, negative events such as the uncovering of accounting scandals, a lack of liquidity or liquidity problems due to higher interest rates, or the difficulty in repaying loans, among other things. Insiders start to sell assets and move them to safety. Phase four 
is therefore referred to as the critical phase or financial distress phase. Phase five is associated with the bursting of the bubble, a drop in prices in the industry, and a loss of confidence. Possible credit defaults at banks and corporate bankruptcies lead to a widening of the crisis to the point of real economic distress. The current development of the Fintech sector fits well into the first phases of this model.

The triggering exogenous shock is the financial crisis of 2008/2009 with the associated loss of confidence in the banking sector. With the help of the use of new technologies, there is a shift towards new financial services and products outside the established banking and financial sector. The increasing profit prospects in the fintech sector lead to increased venture capital investments, increased global total value of investments, and an increasing trend of start-ups. At the same time, the development is favored by the easy overall economic availability of liquidity and credit as well as the prevailing low-interest phase. Currently, according to this model, it can be assumed that the fintech industry is at the end of the second phase or shortly before the beginning of the third phase, the euphoria. For example, the positive news is accumulating and initial risks, especially in lending, are being ignored. Claessens et al. (2018) already point out that some fintech companies, in their expansion drive, may have settled on a higher proportion of riskier borrowers. Thus, should developments in the fintech industry also pass through the further stages of the Minsky model and, as a component of the financial system, also be subject to the "financial instability hypothesis," there is a risk that a new speculative bubble is about to flourish. Combined with the risk of the regulatory dilemma, the danger of a speculative bubble washing up and bursting and a resulting crisis will be exacerbated.

\section{Future Direction}

The purpose of the final chapter is to provide an outlook on possible ideas and research approaches in the field of fintech. These are derived argumentatively from the preceding chapters and are intended to stimulate and expand. Thus, one point that can be noted is that there is a need to concretize the term fintech due to the different definitions and perspectives. The focus can be on a regulatory definition or on expanding the definition to include general fintech functions. Related to this is the field of classification of fintech activities. For example, there are already initial works such as Dorfleiter et al. (2016), Financial Stability Board (2019), and Patrycja (2020), which come to different assessments due to the novelty and heterogeneity of views and definitions. As the market economy develops, existing activities will disappear and new ones will be added. Consequently, the question arises whether there will be a core definition of fintech that can be flexibly supplemented by current developments. One idea for the core is a more precise focus on the use of existing technologies and an examination of which technologies are mandatory and which are complementary for the field of Fintech. Looking at the different reasons and development of Fintech in emerging markets as well as in Europe and the U.S., it may be possible that region-specific definitions regarding Fintech activities will emerge. In addition, a further research approach arises in the context of a country comparison, which examines which Fintech activities are used in which countries and which macroeconomic and microeconomic reasons play a role.

Given the development of a regulatory definition, far-reaching consequences arise as to how regulators will deal with the emergence of fintech. In connection with the described regulatory dilemma, there is also a broad field of further research. Thus, ideas and approaches to solving the dilemma should be found while determining a generally applicable regulatory or legal definition. On this basis, it can be determined whether regulation is necessary. Concerning the scope of regulation, it is also necessary to examine more deeply which fintech activities require which type of regulation. The first approach in this direction is the use of sandboxes. This idea can be further pursued, for example, in the direction of how such a sandbox must be designed, what goals it should pursue, what functions it should map, what country-specific differences there are, etc. At the same time, the question of the economic benefit of this test form should also be answered. In connection with this, it must be clarified how sensible it is to first breed fintech companies in such an incubator to later release them onto the free market. Overuse of closed sandboxes may result in the phenomenon that 
fintech companies are thus deprived of the free play of market forces and artificially grow to a critical size. Consequently, regulatory sandboxes also need to be examined from a market efficiency perspective. Since regulation of the banking and financial sector is carried out both at the national level and the supranational level, a cross-country comparison of different fintech regulatory approaches can provide information on which form is best under which conditions. At the same time, the national commonalities can be used to develop a supranational framework for fintech regulation. As the explanations of the different reasons regarding the existence of Fintech have shown, these are also very heterogeneous. One of the claims that can be made is that fintech companies contribute to the (efficiency) improvement and stability of the financial system. Improvement is seen here in terms of better allocation or better access to/from financial resources. Stability improvement is to be understood as a possible reduction of systemic risk. In addition, a further interesting market-related research aspect is the classification of fintech in the financial ecosystem, such as in Dapp (2016) or Imerman \& Fabozzi (2020). The question here is whether fintech companies are integrated or can be integrated into the existing banking and financial landscape. Due to national differences, it can also be assumed that there are country-specific or region-specific differences that can also be considered as a subject of investigation.

In addition to the assumption that Fintech leads to (efficiency) improvement, another thesis can be put forward. If fintech helps to reduce market inequalities, fintech is capable of driving financial inclusion. Questions that can be focused on here include how fintech and financial inclusion are related, in what ways fintech can drive financial inclusion, why fintech, in particular, is seen as contributing to financial inclusion in emerging markets, and how fintech can spur economic growth in emerging and developing markets. Moreover, especially against the backdrop of the Corona crisis and the associated contact restrictions, there may be effects that have accelerated the adaptation of fintech services in different countries. An initial investigation in this regard is provided by $\mathrm{Fu} \&$ Mishra (2020), for example. Özil (2020) also shows that the Corona crisis has increased financial inclusion. The reasons include greater trust in Fintech, easier and better payment processing, continuous circulation of money, and ensuring that people have enough money at all times during the crisis. For China Bao and Huang (2020) find in an empirical study that Fintech is more likely to grant credit borrowers, as well as those who reside in areas with high COVID cases during the pandemic. This might be one possibility to minimize the negative effects of the crises and in inline with these a further way to foster financial inclusion.

On a microeconomic level or from a management-oriented perspective, it may be of interest which success factors characterize fintech companies and which future business areas, activities, or global players there will be in this area. Closely related to this is the question of the role played by many Bigtechs, e.g. Alibaba, Apple, Facebook, Google, Microsoft, or Tencent, which in their role as a technology group develop the technologies that are normally used by young Fintech companies. Due to the market dominance that these companies have and their know-how, it can be easy for the companies to gain a foothold in the Fintech industry and quickly gain market share up to a dominant position. The first approaches of these companies to enter the fintech market already exist in the area of mobile payments and the development of their cryptocurrency. An initial overview of the various activities is provided by the Financial Stability Board (2019).

A final idea for future research is to look at fintech and its possible potential for speculative bubble formation. Based on the "financial instability hypothesis", it can be hypothesized that the Fintech sector is also prone to bubble formation with a subsequent crisis. It should be investigated whether the thesis applies to the entire Fintech industry or only to selected activities or areas. Since, according to the "financial instability hypothesis", bubbles are triggered by the behavior of market participants, a link to behavioral finance and the hype cycle is a possible approach to approach the question. Moreover, to eliminate a possible bubble, this research approach can be linked to the ideas on fintech regulation to create a holistic framework. 


\section{Conclusions}

Fintech is a phenomenon that is defined and understood differently in the literature. There is agreement that fintech is made up of the words "financial" and "technology". Here, neologism means the integration of technology into the offerings of financial services companies to improve their use and delivery to consumers. This etymological understanding represents the minimum consensus of all definitions and perspectives. To further sharpen the understanding of the term, systematization of the different views and definitions by technological and/or functional focus is proposed. It becomes apparent that each view has its strengths and weaknesses and that a great deal of heterogeneity prevails.

Although Fintech is often seen as an achievement of the last decade, the essence of Fintech goes back to the development of the telegraph and can be divided into three different historical phases. The reasons are given within the article as to why Fintech has skyrocketed since the last decade are as numerous as the definitions and perspectives. The reasons range from the emergence of innovations and technologies to efficiency considerations, to market-oriented arguments that can be categorized as supply-oriented and demand-oriented.

There are also opportunities and risks associated with every new idea or development. This also applies to the phenomenon of fintech. The reduction of market imbalances and asymmetric information, for example, can be seen as an opportunity. Linked to this is also the possibility of advancing financial inclusion through fintech. Furthermore, the rise of Fintech can have the potential to increase global financial stability and offers the opportunity for general efficiency or market improvement. A mere regulatory dilemma arises as a risk. This arises between the inclusion of Fintech companies in the legal regulatory framework and the associated risk of slowing down the development of innovations as well as technologies, and far too lax regulation on the other hand, which can potentially lead to market distortions or shocks. Other risks can be divided into microeconomic and macroeconomic risks.

It can also be said that the topic of fintech offers ideas and starting points for further research. Possible areas include the impact on the banking and finance sector, the relationship between financial inclusion and fintech, and the question of management-oriented success factors that separate good from bad fintech companies. Moreover, since the fintech phenomenon is not limited to a single country or region, the topic offers opportunities for cross-country research.

\section{References}

Allen, F. et al. (2020), "A survey of fintech research and policy discussion", FRB of Philadelphia Working Paper No. 20-21.

Amstad, M. (2019), "Regulating Fintech: Objectives, Principles, and Practices", ADBI Working Paper 1016.

Arner, D. W. et al. (2015), “The Evolution of Fintech: A New Post-Crisis Paradigm?”, University of Hong Kong Faculty of Law Research Paper No. 2015/047, UNSW Law Research Paper No. 2016-62.

Bao, Z., \& Huang, D. (2021). Shadow Banking in a Crisis: Evidence from Fintech During COVID19, Journal of Financial and Quantitative Analysis, 56(7), 2320-2355.

Claessens, et al. (2018). Fintech credit markets worldwide: size, drivers and regulatory issues, BIS Quarterly Review September 2018.

Baba, C. et al. (2020), "Fintech in Europe: Promises and Threats", IMF Working Paper WP/20/241.

Bartlett, R. et al. (2018), "Consumer-lending discrimination in the era of fintech", NBER Working Paper No. 25943.

Basel Committee on Banking Supervision (2018), "Sound Practices Implications of fintech developments for banks and bank supervisors", paper, February 19, 2018.

Beck, T. et al. (2007). Finance, inequality and the poor, Journal of Economic Growth, 12, 27-49.

Beck, T. (2020), "Fintech and Financial Inclusion: Opportunities and Pitfalls", ADBI Working Paper 1165 . 
Berg, T. et al. (2018), "On the rise of fintechs - credit scoring using digital footprints", FDIC CFR Working Paper Series 2018-04.

Branzoli, N. \& Supino, I. (2020), "FinTech credit: a critical review of the empirical literature", Bank of Italy Occasional Papers No. 549.

Chemmanur, T. et al. (2020). Recent developments in the FinTech industry, Journal of Financial Management, Markets and Institutions, 8(1), 2040002-1 - 2040002-31.

Christensen, C. M. (2011). The Innovator's Dilemma. Why established companies lose the competition for breakthrough innovations (The innovator's dilemma, 1997). Vahlen, Munich.

Danker, W. \& BaFin (2016). "FinTechs: young IT companies in the financial market", available at: https://www.bafin.de/dok/7849754 (accessed 02.03.2021).

Dapp, T.-F. (2016). Fintech - the digital structural change in the financial sector, Wirtschaftsinformatik \& Management, 8(3), 26-37.

Das, S. R. (2019). The future of fintech, Financial Management, 48(4), 981-1007.

Deutsche Bundesbank (2016), "Deutsche Bundesbank provides assistance on the supervisory classification of innovative business models for FinTechs", available at: https://www.bundesbank.de/resource/blob/598268/6632dadd444ff7f66d498249a7551017/ $\mathrm{mL} /$ die-deutsche-bundesbank-leistet-hilfestellung-data.pdf (accessed 07.03.2021).

Deutsche Bundesbank (n.d.), "Fintech", available at: https:/www.bundesbank.de/de/aufgaben/bankenaufsicht/einzelaspekte/ fintechs/fintech598228, (accessed 09.03.2021).

Dorfleitner, G. et al. (2016), "FinTechMarkt in Deutschland Final Report October 17, 2016", available

at:

https://www.bundesfinanzministerium.de/Content/DE/Standardartikel/Themen/

International_Financial_Market/2016-11-21-Report.html, (accessed 09.03.2021).

Dorfleitner, G. et al. (2020). The German FinTech Market in 2020, ifo Schnelldienst, 8, 73rd ed.

Durach, C. F.et al. (2017). A New Paradigm for Systematic Literature Reviews, Supply Chain Management. Journal of Supply Chain Management, 53(4), 67-85.

Ehrentraud, J. et al. (2020), "Policy responses to fintech: a cross-country overview", FSI Insights on policy implementation No 23.

Elsinger, H. et al. (2018). Digitalization in financial services and household finance: fintech, financial literacy and financial stability, Oestereichische Nationalbank Financial Stability Report 35 - June 2018, 50-58.

European Central Bank (2020), "ESCB/European banking supervision response to the European Commission's public consultation on a new digital finance strategy for Europe/FinTech action plan. August 2020".

European Parliament (2018), "Report on FinTech: the influence of technology on the future of the financial sector (2016/2243(INI))", Committee on Economic and Monetary Affairs.

Fáykiss, P. et al. (2018). Regulatory Tools to Encourage FinTech Innovations: The Innovation Hub and Regulatory Sandbox, International Practice, Financial and Economic Review, Magyar Nemzeti Bank (Central Bank of Hungary), 17(2), 43-67.

Financial Stability Board (2017), "Financial Stability Implications from FinTech Supervisory and Regulatory Issues that Merit Authorities' Attention”, June 27, 2017.

Financial Stability Board (2019), "FinTech and market structure in financial services: Market developments and potential financial stability implications", February 14, 2019.

Frost, J. (2020), "The economic forces driving fintech adoption across countries", BIS Working Papers No. 838.

Fu, J. \& Mishra, M. (2020), "Fintech in the time of COVID-19: Trust and technological adoption during crises", Swiss Finance Institute Research Paper Series No.20-38.

Goo, J. J. \& Heo, J.-Y. (2020), The Impact of the Regulatory Sandbox on the FintechIndustry, with a Discussion on the Relation between Regulatory Sandboxes and Open Innovation, Journal of Open Innovation: Technology, Market, and Complexity, 6(43), 1-18. 
Heim, S. (2013), "Explanatory approaches of behavioral finance to the emergence and development of the financial crisis", Schriften zur Finanzwirtschaft Technische Universität Ilmenau, Heft 10.

Hikida, R. \& Perry, J. (2019). FinTech Trends in the United States: Implications for Household Finance, Public Policy Review, 16(4), 1-32.

Hochstein, M. (2015), "Fintech (the Word, That Is) Evolves, available at: http://www .americanbanker.com/bankthink/fintech-the-word-that-is-evolves-10770981.html, (accessed 06.03.2021).

Imerman, M. B. \& Fabozzi, F. J. (2020). Cashing in on innovation: a taxonomy of FinTech, Journal of Asset Management, 21, 167-177.

IMF (2018), "The Bali Fintech Agenda", IMF Policy Paper, October 43.

Kerényi, Á. \& Molnár, J. (2017). The Impact of the Fintech Phenomenon - Radical Change Occurs in the Financial Sector?, Financial and Economic Review, Magyar Nemzeti Bank (Central Bank of Hungary), 16(3), 32-50.

Leonhardt, F. \& BaFin (2019), "Evolutionary impact of fintechs on the financial industry", available at: https://www.bafin.de/dok/13253250, (accessed: 02.03.2021).

Minsky, H. P. (1978), "The Financial Instability Hypothesis: A Restatement”, Thames Papers in Political Econocmy, Hyman P. Minsky Archive. Paper 180.

Minsky, H. P. (1992), “The Financial Instability Hypothesis”, Working Paper No. 74.

Mirchandani, A. et al. (2020). Understanding the Fintech Wave: A Search for a Theoretical Explanation, International Journal of Economics and Financial Issues, 10(5), 331-343.

Nathmann, M. (2019). FinTech: Challenges in the Regulation of Digital Business Models Based on Securities Sector Designs, Nomos, Baden-Baden.

Nightingale, A. (2009). A guide to systematic literature reviews, Surgery (Oxford), 27(9), 381-384.

OECD (2018). Financial Markets, Insurance and Private Pensions: Digitalisation and Finance.

Ozili, P. K. (2020), "Financial Inclusion and Fintech during COVID-19 Crisis: Policy Solutions", The Company Lawyer Journal. Vol 8.

Paddags, N. (2017), "Why FinTechs are not disruptive innovators - Notes on theory, state of affairs and strategic implications", in Smolinski R. et al. (Eds.): Innovationen und Innovationsmanagement in der Finanzbranche. Edition Bankmagazin, Springer Gabler, Wiesbaden, pp. 385-398.

Philippon, T. (2017), "The FinTech Opportunity”, BIS Working Papers No. 655.

Philippon, T. (2019), “On Fintech and Financial Inclusion”, NBER Working Paper No. 26330.

Ratecka, P. (2020). FinTech - definition, taxonomy and historical approach, Zeszyty Naukowe Małopolskiej Wyższej Szkoły Ekonomicznej w Tarnowie / The Malopolska School of Economics in Tarnow Research Papers Collection, 45(1), 53-67.

Rupeika-Apoga, R. \& Thalassinos, E. (2020). Ideas for a Regulatory Definition of FinTech, International Journal of Economics \& Business Administration (IJEBA), VIII(2), 136-154.

Schindler, J. (2017), "FinTech and Financial Innovation: Drivers and Depth", Board of Governors of the Federal Reserve System (U.S.) Finance and Economics Discussion Series 2017-081.

Schumpeter, J. A. (1947), Capitalism, Socialism and Democracy, Kessinger Publishing.

Statista Research Department (2021a), https://www.statista.com/statistics/719385/investments-intofintech-companies-globally/ (accessed 23/3/2021).

Statista Research Department (2021b), https://www.statista.com/statistics/893954/number-fintechstartups-by-region/ (accessed 23/3/2021).

Statista Research Department (2020), https://www.statista.com/statistics/412642/value-of-globalvc-investment-in-fintech/ (accessed 323/3/2021).

Štrukelj, E. (2018), "Writing a Systematic Literature Review", available at: https://blog.efpsa.org/2018/01/03/writing-a-systematic-literature-review, (accessed 06.03.2021). 
Thakor, A. V. (2019). Fintech and banking: What do we know? Journal of Financial Intermediation, 41(C), 100833-100858.

TU Berlin (2019), "Systematic Literature Review", available at: https://www.dbwm.tuberlin.de/menue/fuer_forschende_lehrende/methode_systematic_literature_review/, (accessed 06.03.2021).

Varga, D. (2017). Fintech, the new era of financial services, Vezetéstudomány / Budapest Management Review, 48, 22-32.

Volcker P. (2009), "The only thing useful banks have invented in 20 years is the ATM", New York Post, December 13, available at: http://nypost.com/2009/12/13/the-only-thing-useful-bankshave-invented-in-20-years-is-the-atm/, (accessed 03/06/2021).

World Bank (2018), "Financial Inclusion - Financial inclusion is a key enabler to reducing poverty and boosting prosperity", available at: https://www.worldbank.org/en/topic/financialinclu sion/overview\#1, (accessed 19.03.2021).

World Bank (2020), "How Regulators Respond to FinTech: Evaluating the Different Approaches Sandboxes and Beyond", Fintech Note; No. 4. World Bank, Washington, DC.

Yonghee, K. et al. (2015). An Empirical Study on the Adoption of "Fintech" Service: Focused on Mobile Payment Services, Advanced Science and Technology Letters, 114(2015), 136-140.

This work is licensed under a Creative Commons I Attribution-NonCommercial 3.0 Unported License. 